\title{
Et selvransakende nordnorsk museumsseminar ble avholdt $i$ Tromsø i oktober 2006
}

\author{
Gerd Johanne Valen*
}

Title: The 21st North Norwegian museum seminar in Tromsø was a process of self-examination.

Abstract: What are the museums doing? Do people really learn from museum collections or are the inherent restrictions so stringent that these collections are by nature unable to impart new knowledge and understanding? A reform of the Norwegian museum world has taken place in recent years - what methods can we now use to make our exhibitions more interesting?

The many small museums in northern Norway have tried to put on new exhibitions in order to support learning, debate and experience. But why don't we try to evaluate the methods used thus far and to analyse both our audience's understanding of new exhibitions and how they react to these? That might point our museums in new directions, so that they became more self-critical in future.

Keywords: Hands on, strict preservations, dialog/monolog, wide audience /small target groups.

19. og 20. oktober ble det 21. nordnorske museumsseminar $i$ Tromsø arrangert av Tromsø Museum, Universitetsmuseet. Temaet for seminaret var museet som kunnskapsformidler $i$ en ny tidsalder; et velkjent tema fra de siste ti arene. Jeg ble oppfordret til a skrive en kort vurdering av seminaret. Det betyr at jeg trekker fram noen fä poenger fra de forskjellige innleggene og kommenterer disse, for jeg avslutningsvis kommenterer Tromsø Museums rolle som landsdelsmuseum.

\section{BEVARINGSHYSTERIET OG SAMTIDEN}

Kerstin Smeds professor i museologi ved Umeå Universitet startet seminaret med et innlegg om"Försvinnandets kultur och samtidens mumifiering- vad är det vi håller på med?" Hun mente at museene nå må begynne å bruke museumsgjenstandene aktivt. Hun oppfordret oss til å bruke vår kulturarv. Smeds mente at museene selvfølgelig må i vareta noe for ettertiden, men at man har latt det gå for 
langt med å bevare. Publikum må kunne se på plagget eller den hjemmesnekrede stolen, finne ut hvordan det er laget og med hva. Smeds oppfordret museene til å la folk få lov å kopiere og lære av museumsgjenstander. Mange museer har praktisert "hands on"- museumsgjenstander i en årrekke, både bevisst og ubevisst. Det som er interessant er å vite hvordan publikum reagerer i forhold til slike utstillinger og om det øker interessen for gjenstander som kildemateriale. Gjenreisningsmuseet lagde i 1998, fem såkalte autentiske rom for at de besøkende skulle kunne ta på, sitte i og studere gjenstander fra den provisoriske og permanente gjenreisningen. En evaluering av publikums reaksjon og forhold til disse rommene kunne gitt oss en pekepinn på om dette er en fruktbar utstillingsmetode.

Smeds hevdet at uansett hvor mye vi konserverer og magasinerer vil ikke gjenstandene vare evig. Bevaringshysteriet og monterterroren står dessuten $\mathrm{i}$ veien for formidlingen. Årsaken til dette bevaringshysteriet mente Smeds var at vi har kuttet båndet mellom nasjonen og historieskrivningen. Nå er alle historiene og alle gjenstandene like viktig å bevare. Samlingene viser kun vårt kontrollbehov, og hva vi for ettertiden vil framheve som verdifullt. Mens sannheten om hver tidsepoke ligger et sted mellom søppeldungen og museet.

Kerstin Smeds innlegg var spennende spesielt med tanke på hvordan hun forklarte vår tids bevaringsraseri som et produkt av at vi mumifiserer samfunnet og at vårt vestlige samfunn ikke har noen positiv framtidsvisjon.

Perspektivet Museum har valgt en ressurskrevende veg med mange temporære utstillinger og med mange perspektiver. Deres oppgave er å nå spesielle målgrupper med forskjellige tema. Museumssjef Astrid Fremmerlid fortalte om "Samtiden på museum - samfunnsoppdrag i endring." Hun beskrev museets metode som redaksjonell når de ansatte stiller spørsmål, undersøker og lager utstillinger som de håper vil fremme debatt. Men er ikke dette den generelle metoden for alle utstillinger? Lar de andre enn museets ansatte stille spørsmålene, gjøre undersøkelsene og lage utstillingene? Er Perspektiv Museum et annerledes museum eller er de bare mer ressurskrevende? Kan et museum i Honningsvåg, Nesseby eller på Svalbard konsentrere seg om å lage utstillinger bare for ei spesiell målgruppe?

\section{MONOLOG ELLER DIALOG OG MED HVEM?}

Forsker Kjell Hansens innlegg om"Kunnskap, existens och utställning; vad museet kan säga sina besökare", tok utgangspunkt i et utstillingsprosjekt som han hadde deltatt i og mente var mislykket. Han mente at museene har oppdradd publikum gjennom år til å ta i mot det som blir presentert i utstillinger og at de ikke er oppdratt til å stille spørsmål. Publikum tar i mot museenes monolog og er ikke innstilt på dialog. Museene har dermed lyktes i å få publikum til å tro på sine presentasjoner, og det blir vanskelig å dekonstruere virkeligheten $i$ et postmoderne samfunn. Jeg tror museene fremdeles har mulighet til å oppdra publikum. Dersom museene klarer å sette teoriene ut $\mathrm{i}$ praksis og tror de kan gjøre en forskjell med utstillinger, undervisning og aktiviteter, så er dette mulig. Jeg tror ikke oppdrager rollen er forsvunnet. Kommunikasjon eller dialog kan også læres.

Midt-Troms Museums "Rovdyrutstilling" som handler om rovdyr og rovdyrproblematikk i Norge, hadde derfor også fortjent en presentasjon. Hvilke valg og metoder gjorde 
122 museet under planleggingen av utstillingen? Oppnådde de dialog med publikum og skapte de debatt i lokalsamfunnet?

I 1. amanuensis Stein Mathisens innlegg om "Museum og fortellinger om kulturell forskjell" savnet jeg en rundreise og vurdering av museene i Finnmark. Har museene tatt kulturlikheter og forskjeller på alvor? Han fortalte om ei utstilling i London som benyttet levende samer som utstillingsobjekter på slutten av 1800-tallet, før har gikk over til å vurdere de samiske utstillingene til Tromsø Museum. Kanskje var skuffelsen over eksemplene han ikke benyttet så stor at jeg mistet poenget med hele innlegget. Jeg satt igjen med en gammel visshet om at den samiske kulturen er ikke statisk, men består av aktører og at kravet til museene om å være møteplasser likegodt kan skapes rundt et ildsted.

Det pedagogiske grepet, aktivitetene, utstillingen "Stàllobiedju" og bruken av ute-området til Varanger samiske museum hadde kanskje vært mer spennende å presentere enn gamle utstillinger som de fleste som arbeider i landsdelen har relativ god kjennskap til.

Rådgiver Merete Frøylands innlegg skulle handle om "ABM-meldingen oppfordrer museene til å være samfunns-og dialoginstitusjoner, møteplasser og informasjonskilder- på hvilke måter utfordrer dette museumsformidlingen?" Hun påsto at gjenstandene får for mye oppmerksomhet i museenes virke. Misjonen med innlegget var å sette publikum i sentrum når museene lager utstillinger. Målgrupper var et essensielt poeng. Hun hevdet at man kan ikke lage museums utstillinger til alle. Jeg mener at i et område med et befolkningsgrunnlag på 2 - 10.000 er dette faktisk nødvendig. Det krever bevisstgjøring av alle som deltar i utstillingsprosessen. Når design og formidlingsideen smelter sammen og formspråket blir så tydelig at det skaper fortellinger eller stemninger som kan oppleves, da er man på god veg til ei utstilling for alle. Samtidig kan man lage ei utstilling med flere nivåer. Ei utstilling bør være en balansegang mellom kunnskapsformidling og opplevelse. Hvorfor lage utstillinger kun for barn- og unge når de fleste museene samtidig har museumspedagoger som legger utstillingene til rette for undervisning?

\section{NYE FORMIDLINGSPROSJEKTER}

Andre dag ble tanker rundt tre nye formidlingsprosjekter presentert. Her ville det vært naturlig at Svalbard Museums nye basisutstilling som ble åpnet i april 2006 ble presentert.

Prosjektleder Alf-Einar Øien innlegg "Er det mulig å gjøre et litterært museum for de få til et opplevelsessenter for de mange? Krav, hensyn og utfordringer av Hamsunsenteret på Hamarøy." Han ønsket at Hamsunsenteret først og fremst ble et opplevelsessenter og ikke et museum, og ville basere seg på en ny kompetanse. I stedet for mange ansatte ønsker de å trekke veksler på kompetansen som allerede eksisterer i regionen. De ser for seg at moderne teknologi skal dominere og har engasjert teknologer ved høyskolen i Narvik og kulturfaglige ved høyskolen i Bodø i prosjektet. Samtidig ønsker de å anvende forskning om Hamsun som foregår på Universitetet i Tromsø.

Zoolog Kjetil Sagerup stilte spørsmål om: "Har den tradisjonelle museumsutstillinga utspilt sin rolle som formidler av den levende naturen? Tanker rundt den nye zoologiske basisutstillinga "NaturligVis". Han fortalte om publikums reaksjon da Tromsø Museums zoologiske utstilling ble tatt ned. Dette var en ut- 
stilling hvor dyrene var plassert i såkalte habitat, uten forbindelse til hverandre. Publikum ble opprørte og ønsket den tilbake. Men museet planlegger ei ny og mer moderne utstilling. Museet hadde forsøkt ved blant annet å se til Paris for å finne et godt eksempel på ei moderne zoologisk utstilling. Denne ga ingen inspirasjon til etterligning fordi dyrene her var tatt helt ut av sin sammenheng. Kjetil Sagerup ønsket derimot at ei ny zoologisk utstilling skulle vektlegge økosystemet og menneskeskapte endringer i naturen. Siden han ikke hadde noen gode moderne eksempler å vise til vil jeg anbefale en studietur til Svalbard. Samspillet mellom natur og kulturhistorien på Svalbard og økosystemet har en sentral plass i Svalbard Museums utstilling. Om utstillingskonseptet fungerer hadde vært nyttig å få vurdert fra kollegaer med erfaring fra zoologiske utstillinger.

Arkeolog Morten Ramstad presenterte formidlingsprosjektene etter de arkeologiske utgravningene i forbindelse med Statoils Snøhvit-prosjekt utenfor Hammerfest. Han snakket om "Steinalderutstillingen: Ilden i sentrum. Konsept, målsetting og evaluering". Utstillingen er laget for målgruppen 10-16 år. Utstillingen skulle være ei "hands-on" utstilling, interaktiv og skjermbasert. I tillegg skulle den ha utfordrende fargebruk og form.

Denne utstillingen var det eneste av prosjektene som seminardeltakerne selv kunne se. Tromsø Museum åpnet utstillingen i juli 2006. Dessverre fikk jeg ikke med meg innlegget til Kjetil Lobben som er konseptutvikler i firmaet Expology. Formgivernes tanker bak konseptet måtte jeg heller vurdere ved å se utstillingen. Den bar tydelig preg av å ikke være ferdigstilt. Design og formidling hadde heller ikke smeltet sammen til et felles formspråk, men ga mer inntrykk av en innbyrdes kamp i to motstridende retninger. Balansegangen 123 mellom kunnskap og opplevelse haltet. Kanskje ikke rart at foto og tekst allerede holdt på å løsne fra veggene? Selvfølgelig hadde konseptet elementer som fungerte og med en god museumspedagog eller lærer kan man aktivisere ungdom i denne utstillingen.

\section{GJENSTANDEN KILDE TIL KUNNSKAP ELLER EMOSJON?}

Arkeolog Kristine Sørgaard stilte spørsmålet: "Er det mulig å revitalisere gjenstanden som fascinasjonsobjekt?” Hun ønsket å revitalisere gjenstanden, og hevdet at bare $5 \%$ av gjenstandene i museene benyttes til forskning og formidling. Hun gikk i mot de som mener at museene er for opptatt av gjenstandene og derfor ikke er aktive og utadrettede. Derimot mente Søgaard at museene er i ferd med å svikte sitt eget grunnlag og at vitenskapen har sådd tvil om gjenstanden som kilde til kunnskap. Oppskriften til Søgaard er å sette magasinet i sentrum som selve hjertet i museumsvirksomheten. Men i stedet for det åpne magasinet som Smeds anbefalte, å la publikum lære av gjenstandene, så er et kontrollert, strekkode- styrt, lukket og databasebasert magasin Sørgaards forbilde. Kan et lukket magasin være strategien for å gjøre gjenstanden til en vitenskapelig kilde eller et fascinasjonsobjekt?

Fil dr. i etnologi Eva Silvèns hadde et innlegg om "Dialog, emotion, autenticitet- om museers och människors föremål" Hun trakk fram utstillingen "Svåre saker", en ambulerende svensk utstilling fra noen år tilbake. Hun viste til ei utstilling som stilte ut gjenstander og historiene om dem og at begge deler var en forutsetning for hverandre. Hun mente at sam- 
124 lingene må komme $\mathrm{i}$ fokus og at museene gjerne må flytte gjenstandene inn i den politiske samtalen. Dette er selvfølgelig et godt råd, men heller ikke utstillingen "Svåre saker", viste noe mer enn vanskelige saker og deres historie. Mange gjenstander har knyttet unike historier til seg og dersom vi ikke tar gjenstandsamlingene på alvor og samtidig samler inn historiene som er knyttet til dem er museene med på å så tvil om gjenstandenes betydning som kilde både til metoder og levd liv. Men å våge å ta et politisk standpunkt i en utstilling er et toegget sverd og kan også støte publikum. Vil tydelige politiske budskap gi bedre utstillinger?

Personlig synes jeg at ei utstilling uten gjenstander er som å lese en avis. Museenes fordel i forhold til alle opplevelsessentrene er nettopp gjenstandene. Gjenstandene er tredimensjonale og unike, og kan oppleves i flere kontekster. På grunn av at ekstreme bevaringsprinsipper har fått råde i altfor mange år er ofte gjenstandene utilgjengelige og publikum har ikke mulighet til å oppleve gjenstander skjult i mørke og bak glass. Dermed blir heller ikke interessen for objektene som kilde til kunnskap aktivisert, og magasinene blir museenes dårlige samvittighet. Er det ikke nettopp å anvende forskning og ny kunnskap som burde være museenes hovedoppgave?

\section{TROMS $\varnothing$ MUSEUM, UNIVERSITETSMUSEET SOM LANDSDELENS FYRTÅRN?}

Det 21. nordnorske museumsseminar var et selvransakende seminar. Innleggenes titler burde alle ha sluttet med "Hva er det vi holder på med". Tromsø Museum var engang et landsdelsmuseum. De arrangerte seminarer hvert år. Så ble det slutt. Andre museer ble ar- rangører og i 2002 ble det siste seminaret holdt i Hammerfest. Tromsø Museum konsentrerte seg om å bli Universitetsmuseet, men ble de fyrtårnet blant museene i landsdelen? Programmet til dette seminaret kan tyde på at de ikke har klart å være drivkraften i museumsdebatter, nye utstillinger og aktiviteter i landsdelen. Det finnes mange gode eksempler fra utstillinger og formidlingsprosjekter i landsdelen som burde ha vært presentert, men kanskje Tromsø Museum ikke hadde kjennskap til dem? Likevel er det god terapi både for eldre og nye museumsansatte i landsdelen med repetisjoner og selvransakelser. Museene skal tjene samfunnet og hvordan vi best kan gjøre det bør stadig være på dagsorden.

Seminardeltakerne ytret ønske om at de nordnorske seminarene må fortsette. Dersom dette blir en årlig foreteelse bør man invitere museumsansatte til å presentere nye utstillinger og nye formidlingsgrep for barn og unge som foregår i landsdelen. La dem fortelle hvorfor de valgte de metodene de gjorde da de laget sine prosjekter. Enkelte analyser av publikumsundersøkelser er også fruktbart å få presentert. Mange av de som jobber med å skape nye utstillinger eller andre formidlingsprosjekter har et sterkt ønske om å omsette de teoretiske forståelsene til en god pedagogisk utstilling. Andre ønsker å skape gode læringssituasjoner for barn- og unge. Atter andre ønsker å skape livlige debatter. Mange museer anvender forskningen som foregår $\mathrm{i}$ landsdelen og har innledet et ikke- formalisert samarbeid med Universitetet i Tromsø og høyskolene. Museene sitter dessuten med oversikt over behovet for ny kunnskap som er viktig for forskningen som bør foregå i landsdelen.

To dager i Tromsø var over. Hadde selvransakelsens timer gitt oss utvidet kunnskap, skapt nysgjerrighet og entusiasme for våre framtidi- 
ge museale oppgaver og utstillinger? Jeg tror at

seminaret hadde vært mer fruktbart dersom problemstillingen var hvordan museene, siden museumsreformen kom, har forsøkt å ta oppfordringa til ABM-utvikling på alvor. Dette bør være hovedspørsmålet for et eventuelt nytt seminar.

Dersom Tromsø Museum tar på seg rollen igjen som landsdelsmuseum og ønsker å ha en ledende posisjon blant museene i nord, må de lytte til det som foregår i deres nærmeste omland og samtidig fortsette å invitere klarsynte foredragsholdere fra inn og utland.

* Gerd Johanne Valen var fra 1996 prosjektleder og museumsbestyrer for Gjenreisningsmuseet for Finnmark og Nord-Troms og hadde ansvaret for at det nye museet $i$ Hammerfest ble åpnet for publikum i juni 1998. Fra 2003 var hun prosjektleder og senere museumsbestyrer for det nye Svalbard Museum som åpnet $i$ april 2006 med ny basisutstilling i Svalbard Forskningspark.

Address: Gerd Johanne Valen, postboks 415,

9171 Longyearbyen. Norge.

E-mail: gerdjv@svalbardmuseum.no 